\title{
Teaching Mentally Handicapped Children (MHC) Using Audio-Visual Aids: A Pedagogic \& Psychoneurolinguistic Approach
}

\author{
Sadeq Ali Saad Al-Yaari (Corresponding author) \\ Independent Researcher, Dept. of English, College of Arts, King Saud University (KSU) \\ Riyadh, Kingdom of Saudi Arabia. Tel: 966-55212-6685. E-mail: prof.sadeq@gmail.com
}

Fayza Saleh Al Hammadi

Associate prof., Dept. of English, College of Arts, King Faisal University, Al-Hassa

Kingdom of Saudi Arabia. E-mail: viceii.library@kfu.edu.sa

Salah Ayied Alyami

Assistant professor, Dept. of English, Dammam University

Riyadh, Kingdom of Saudi Arabia. E-mail: salah1sa@yahoo.com

Received: January 1, 2013 Accepted: January 10, 2013 Published: January 17, 2013

doi:10.5296/ijele.v1i2.3062 URL: http://dx.doi.org/10.5296/ijele.v1i2.3062

\begin{abstract}
Background: Over the years, Audio-visual aids used to aid in the communication of our everyday ideas mainly those related to pedagogy which normally takes place in classrooms.

Aims: As a correlational research, the purpose of the present study is to focus on addressing how and why certain audio-visual aids are used to teach Mentally Handicapped Children (MHC). The aim is to measure whether or not using these Audio-visual aids affects positively the performance of MHC in comparison to their classmates who do not use them.

Method: A total of $157 \mathrm{MHC}$ ( girls=67, and boys=90) with severe receptive disorders, and presented as bewildered MHC at al-Malādhresidential school of Dhamār city in Yemen participated in this study. The age of 87 of them ranges between 5 to 12 years old. Students were divided into two groups: the first group was put in classes equipped with audio-visual
\end{abstract}


aids while the second group was put in classes with no audio-visual aids at all.

Conclusions: Results show that audio-visual aids found to be effective on MHC's performance. These audio-visual aids play an important role in teaching MHC who enjoy them and benefit from them. Audio-visual aids allow more professional and entertaining presentation for teachers of special education who use them to elicit desired response made by MHC. More importantly, they serve as means of treatment when teachers use them properly according to the size and nature of the impairment of MHC. The results suggest that teachers cannot teach MHC without using these audio-visual aids as means for teaching language components and skills.

Keywords: Mentality, Handicapped, Children, Special Needs, Pedagogy, Audio-visual Aids 


\section{Introduction}

Historically speaking, it was in the 18th century when people started to change their opinions about mentally handicapped people. For example, in France, Mentally Handicapped Children (MHC) were sometimes considered good people and magicians and witches in some other times. French people, to some extent, changed their minds about this social class and started to look at them as sick persons. In fact, the expression "mentally handicapped children" (before it is changed by the UN to become people with impairments) is often released on children who show wide range of intellectual functions and social skills. These people are also known as people who have some difficulties (e.g., toilette, feeding, etc.) and are usually recommended to attend developmental nursery or special needs' centers.

Clearly speaking, some of these MHC have mental problems resulting in learning disabilities only, while others have both learning disabled and handicapped. Gregory (1992) explains this point by stating that"... A person can be both learning disabled and handicapped in other ways (e.g., mentally retarded)." (Gregory, 1992, P.326)

The important point is that the coexisting handicapping condition must not be the primary cause of the learning difficulty. Levenson (1967) has mentioned some causes of mental retardation and lists them as follows: "Heredity, parental causes, German measles, Rh. factor, irradiation, emotional state of the mother, consanguinity, age of parents, birth abnormalities including insufficient oxygen in brain, delivery, brain hemorrhage, prematurity, cretinism, mongolism; infections and these, in turn, include syphilis, encephalitis, and meningitis; chemical positions including load, trauma, nutritional deficiencies, congenital and acquired causes." (Levenson, 1967, PP.109-19)

In 1920s of the previous century, MHC were being sent to certain families to take care of them, teach them crafts like knitting, food preparation, simple carpentering, and little about reading and writing skills. In1930s, most of MHC's programs shifted from the ordinary way into the professional methods like academic skills e.g., assisting reading, writing, speaking, etc. In 1940s, the educational systems expanded to include music, mathematics, sports, social studies, science, language, etc. There is no consensus among pedagogueson specific methodology to be used for teaching MHC. Some psychoneurolinguists believe that MHC grow up gradually, and learn, and acquire experiences, information, skills in a gradual way too. The growth of MHC's brains stops below the level where it should be in the case of normal children. It is for this reason that what MHC learn is similar to what normal children do taking into consideration time differences. Put in other way, what is learned by the former in two or three years is learnt by the latter in less than a year.

Some pedagogues and psychoneurolinguists agree that MHC differ from their partners (normal children) socially, psychologically and physiologically; thus, educational methods and programs used for them are quantitatively and qualitatively different from those of normal children. It is almost agreed upon most psychoneurolinguists in general and pedagogues in particular that audio-visual aids play an important role in the pedagogical processes. For instance, computers enhance the interests of the learners (especially children) by motivating them to learn and understand easily. In fact, these audio-visual aids become 
much more significant when they are used for teaching MHC who are attracted by their shapes, sizes, colors, etc.

Despite their incomparable benefits, some pedagogues complain that audio-visual aids are valueless and worthless, especially when they (pedagogues) receive bad signs (negative feedback) from their MHC. They also complain that there may be some indications that these audio-visual aids do not improve the performance of these MHC. It is true that audio-visual aids maybe ill-chosen, mal functioned or even poorly applied, but this does not mean that they themselves fail to perform the purpose they are made for. They can be used as good means for helping learners, especially those children who suffer from mental impairments or language disorders. They can also be effectively used not only to attract learners, but also to maintain their attraction as much as possible. Moreover, audio-visual aids can be successfully used to clarify senses of words and meanings of utterances. We can also invest them to increase chances of remembrance of the learners, especially those who have some psychological and /or mental problems like the participants under the question. In brief, they can be used to save time, efforts, and money.

An important conclusion ought to be drawn here is that child-based audio-visual aids evaluation is one of the processes that has great potential for determining how successful and effective aid is likely to be with any group of learners of special needs in general and those MHC in particular. It remains a process that may meticulously be implemented in the classrooms where these MHC study. The more proper the time and place audio-visual aids are used, the more effective they become, and the better results pedagogues, psychoneurolinguists and SLP/Ts get. In this regards, Stowitschek et al., (1980) agree that:"Teachers need to manage, augment, or replace materials so that instruction culminates in the attainment of the desired goals." (Stowitschek et al., 1980, P.188)

\section{I.1 Aims of the Study}

The current study aims at clarifying how audio-visual aids could be effectively used to teach $\mathrm{MHC}$ and affect their performance. More importantly, it aims at answering the following questions:

1. As essential requirements in their curricula and syllabi, how can schools teaching students of special needs benefit from audio-visual aids?

2. What are the suitable audio-visual aids that can be used to teach MHC and how? Is there relationship between using these aids and the performance of MHC?

\subsection{Methodology}

Performance of $157 \mathrm{MHC}$ use audio-visual aids in their classes was evaluated in comparison to other MHC who study in classical classes with no audio-visual aids. All MHC are current students at al-Malādh school for teaching students of special needs, Dhamar, Yemen. Since correlational studies require studying groups, the larger the better, the researchers used 157 MHC as participants (Two thirds of them are girls and the rest are boys). The age of 87 of them ranges between 5 to 12 years old and the age of the rest (70) ranges between 13 to 17 
years old. In addition to the participants, evaluation also includes all available audio-visual aids including realia, models, visuals aids, sets/ series, mini language labs, T.V, video, cassettes, tape slides and computers. Samples of the curricula and syllabi, tests, drills and exercises are also included. Registration and admission forms and medical records of all participants in addition to the teachers and students' interviews are also taken into consideration. All procedural principles of research ethical report including consent letters, permissions, etc., were undertaken.

Having collected the data, evaluation process started by comparing the performance of the participants under question along with their Pedagogical environment (Classes equipped with audio-visual aids and professional curriculum and syllabuses) to other MHC at school along with their normal environment (with no audio-visual aids or professional curriculum and syllabi).

\section{Information Background}

Early in the 20th century, Pedagogues classified mentally handicapped people as well as other intellectual retarded ones into three groups: absolute, relative and apparent. Discussing the relative group in all its aspects including the Intelligence Quotient (IQ) of its individuals, Matthews (2011) concludes into saying that general education is one of the reasons behind the slow learner, and that teaching of industrial arts is important for MHC as it makes them suited to their environment. Pedagogues started to suggest activities like art activities that might help MHC to forget about their suffering and enjoy their life (Wiggin, 1961). Some of these pedagogues traced the relevant literature on the subject to see whether or not crucial solution for the permanent problems of $\mathrm{MCH}$ can be found (Colette, 1965); others recommended developing and evaluating auto-instructional programs for MHC, notably arithmetic ones due to their non-finite usefulness (Higgings et al., 1967).

With the passage of time, many pedagogues, psychoneurolinguists, and Speech Language Therapists (SLPTs) realized the importance of audio-visual aids for pedagogical purposes and decided to make use of them as effective means (tools) for teaching MHC. These audio-visual aids can be classified as realia (e.g., candles, whistles, piano, smart study machine, mirror, bubbles, etc.), models (Three dimensions like model of train, cars and other transportation means, animals, etc.) visuals aids (Two dimensions that cover different types pictures including simple pictures e.g., a car, a table, etc., composite picture e.g., a scene in the class, etc. and sets or series e.g., stories made for MHC, etc.). Other aids include mini language labs, T.V, Video, cassettes, tape slides, computer, specimen, demonstrations, recordings, transcripts, tapes, film strips, videotapes, radio, reel, Compact Disk (CD), Television (T.V), Digital Video (DVD), Computer, etc.

In one of his researches titled: "Imitation of Language by Mentally Handicapped Children: A Language Assessment Technique", Berry (1973) presented two of his experiments on elicited imitation of language: The first experiment was carried out by him and one of his colleagues. Results of the first experiment show a very strong correlation between elicited imitation and comprehension of sentences. In the imitation task, the children as before were simply asked to "say what I say, say...." followed by the sentence. In the comprehension task, they were 
asked to "show me..." followed by the sentence. The main finding was that there was a very strong relationship between imitation and comprehension of the sentences. In general, sentences which were correctly comprehended by MHC were also imitated at a high level-even if imitation errors occurred; they did not indicate loss of meaning. This experiment indicates relative contribution of both types of assessment techniques.

The second experiment was carried out by Berry (1976), concerning the relationship between languages produced by MHC both when asked to tell the experimenter about a series of pictures and then, to imitate sentences. The production experiment used various types of pictures include:

i. Anomalous pictures, in which the child had to tell the experimenter what was wrong (e.g., a picture of a tea-pot with two spouts).

ii. "What's happening" pictures in which the child had to tell the experimenter what was about to happen (a lady just about to walk into a large puddle of water).

iii. Multiple action pictures in which children play football, climbing trees, fishing, etc. (in all, ten actions were depicted in each picture).

However, the researchers were interested in investigating whether or not MHC use the same language structures in the production and imitation tasks. Commenting on the two experiments, Berry has rightly stated: "We found again a very high degree of relationship between the two tasks and once again concluded that elicited imitation of language reflected overall linguistic ability and in particular the language structure used by mentally handicapped children in production." (Berry, 1976, P. 59)

Jack et al., (1971) proposed building home-made equipment for MHC through which they can practice physical activities. Bacon (1976) believes that the best way of utilizing audio-visual aids is to use them in scientific ways and compare them to see which one of them matches these MHC. Some others took another direction by comparing MHC to each other be it in terms of learning disability, educability, and training (Orfitelli, 2011) or in terms of auditory or a combination of both (Marks, 2011). Other researchers decided either to improve specialist handbooks to help teachers deal with MHC (Walrich, 2011) or draw an ortho-pedagogic guide lines for MHC curriculum-designs (Muller, 2011) that contain musical learning to be used by both normal and MHC (Nocera, 2011). Others looked at it from another different perspective either through designing tests (Sechrest, 1981) or designing signal subjects to test the scientific learning process of MHC (Morales\& Macarena, 2011). Some pedagogues, psychoneurolinguists, and SLTs suggested utilizing new techniques as instrumental music skills' method (Roesene, 1982), Portage technique (a home-based teaching technique) to be used for MHC (Wilson (1985). Others proposed interventions designed to help parents teach their young MHC (McConachie \& Mitchell, 1985).Comparing interpersonal and concurrent procedures when teaching picture names to three $\mathrm{MHC}$, the generalization tests of Rowan \& Pear (1985) show that picture names that were retained in both conditions tend to generalize equally to a different setting and tester, and to the objects depicted in the pictures. 
In the second half of 1980 s, the movement of the studies began to change towards finding practical aids that guarantee involving these $\mathrm{MHC}$ in learning the process including vocational training aids (Steenkamp, 2011).As time passes, the orientation moved towards investigating psychological issue as can be seen in the study of Dipalma-Meyer who in 2011 evaluated the effects of social learning curriculum on developing the adaptive social behavior competence of MHC. Some researchers broadened their researches about MHC to include learning programs with reference to open learning in terms of distance learning ( $\mathrm{Du}$ Toit, 1986). Others started to evaluate the methods used by other researchers, attempting to find out the easiest way for educating MHC that may help them create new methods like Phaup who, in the late 2011, suggested new method called "keyboarding" to be used by MHC (Almeida, 1987).

Investigating the effects of using model status aid on Mild Mentally Retarded (MMR) children, Dagger (2011) concludes that improved accuracy performance supports the use of High status High efficacy Models (HHM) in educating MMR children. Nor must we forget that there was failure to demonstrate an effect of self-efficacy upon skill acquisition which, in turns, raised doubts as to the generalization of the findings of this study declares. Not only the effects of using model status aid on MMR have been investigated, but also researchers drew attention to the effects of using audio aids because of their immense effects on MHC. For example, Manșūr (1989) suggests "using cassette recorder with silent file so that the student can listen, repeat and interact with the silent film.”(Manșūr, 1989, P.173)

Because of the tremendous advantages of computer, both Computer Assisted Language Learning (CALL) (learning) and Computer Assisted Language Instruction (CALI) (teaching) have been broadly used in the process of teaching MHC. Results of Spenciner (2011)'s study show that under the lesson conditions that include speech, more words are identified than one can find in the non-speech condition. In fact, uses of computer extended to include special education (Grandguillot, 2011). This revolution in CALL led to another revolution in instructional models that have been used as means through which MHC could be given effective tasks on leisure and creation like one-to-one instruction task that are found to besuperior in terms of effectiveness and efficiency (Burroughs, 2011). Curriculum Packet is another audio-visual aid tested by Upham (2011) to investigate its adaptability and usability for MHC. The researcher concludes to stress that a watered down regular education curriculum will not meet the needs of MHC.

Investigating old audio-visual aids to see whether or not they can be used for pedagogic purposes today, the study of Van Vuuren (1995) concludes that past audio-visual aids proved to be helpful for $\mathrm{MHC}$, notably those who live in South-Africa. Other researchers investigated how the past pedagogicaudio-visual aids could be differently used for MHC in light of some theories and hypotheses. Jooste (2011), for example, examined Sternberg's Feuerstein's Structural Cognitive Modifiability Theory (FSCMT) and found that audio-visual aids, according to the concepts of the above mentioned theory, fit MHC, notably for teaching 
some syllabi and other classrooms practices. Another similar study conducted by Sa'id\&Hasan (1998) resulting in the fact that the reason behind "this failure goes back to the dereliction in special education programs' targets because of the negativity of the school and education administration, not because of the use of interesting teaching methodologies for children of special needs." (Sa“id\&Ḥasan, 1998, P. 317)

Another study similar to the above mentioned ones, but this time it was carried out by National Center for Educational Researches of Educating Children of Special Needs in Egypt (1999). Results of this study show that "there are some negligence in healthy, social and educational services in achieving the aim-goals of special education and its schools which hinders achieving educational opportunities among normal children and MHC." (NCER, 1999, P.3)

Based on such results, some researchers suggested using computers in education. In his article titled: "Systems of Education via Computer" Yunus (1999) justified one of the necessities for using computers. According to him, computers provide alternative options for those who suffer from certain impairments where "consumer uses various paths which make it easy for him to reach sufficient level of both theoretical and practical knowledge." (Yunus, 1999, P.164)

Attempting to classify MHC on the basis of scientific criteria, outlined results of the study of 'Abdulghaffär (2003) show that $54.4 \%$ of MHC's pedagogues disagree with the fact that the degree of impairment is still under legitimate levels of MHC's standard classification and that $59.5 \%$ them do not agree that multi-impairment is also included in this classification. ('Abdulghaffār, 2003, PP.19-26)

Modern studies focused on how audio-visual aids could be improved to guarantee the best results for these MHC. According to al-Mūsā (2005), changes in teaching methods...... are some benefits of using electronic learning. (al-Mūsā, 2005, PP.118-119)

Some researchers believe that concentration should be directed towards the most influential factor in the pedagogic process i.e., the teacher taking into consideration his belief, professional preparation, the challenges he is facing, etc. (Olivier\& Williams, 2005; Elissa et al., 2005). Others believe that attention should be focused more on various audio-visual aids, not only a particular audio-visual aid. To that end, al-Nawāysa (2007) points out that "using different aids for the same learning purposes help learner get closer to the concepts' meanings." (al-Nawāysa, 2007, P.33)

Other researchers paid more attention to the use of computer which became now the "second teacher" for its multiple uses that covers MHC and which according to al-Jābirī \& Mināyzīl (2008) fall into two broad categories:"The Computer as a tutor and the Computer as a tool. (al-Jābirī \& Mināyzīl,2008, P.9)

Some countries attempted to merge MHC with socially normal students, but the results were not encouraging. In her research titled: "Merging children of special needs with basic education in Egypt in View of the International Contemporary Directions.", results of Ali 
(2008)'s study show "an obvious decrease of number of mentally handicapped children in elementary school to $69.8 \%$ due to bad services preserved to them." (Ali, 2008, P.118)

According to 'Amir\& Muhammad (2008), "in1975, there were over 450 million handicapped people worldwide. However, this number rose to 530 million in 1992, with most of them found in developing countries, 85\% MHC are below 15 years old. In the Arab world, the number is 9 million. In 2001, 3.5-7.5 millions are children and the number in the next few years will increase to 14 million handicapped people and according to UNESCO 12,276,506 are below 24 years old." (“Amir and Muhammad, 2008, PP.104-108)

\section{Analysis \& Discussion}

\subsection{Audio-visual Aids in Schools' Curricula and Syllabi}

Prior to any further discussion, it should be noted that schools teaching students of special needs in Yemen used to be non-governmental. Recently, the government has decided to add this type of schools to the governmental sector. However, such procedure does not necessarily mean that these schools must follow the same system followed by other governmental schools. It only means that these schools are financially and administratively guided and instructed by ministry of education.

Certainly, the audio-visual aids used at al-Malādh school as well as many of its nature are differently used for specific purposes (based on the type of language disorders MHC are suffering from). In that sense, it can be said that the pedagogic strategies in these schools are almost independent. These schools have their own pedagogic objectives, methods, courses, syllabi, etc. Because of the fact that students here are, psychologically speaking, abnormal (In fact, we cannot even call them students), they are treated in special way.

Evidently, the syllabi of schools teaching students of special needs depend basically on audio-visual aids. Armed with books on phonetics, phonology, morphology and psychology, Pedagogues, psychoneurolinguists, and SLTs in these schools prepare their lessons. They start by setting the objectives then they prepare their materials, write their lessons, and apply them in light of the available audio-visual aid.

Before starting the lesson, psychoneurolinguistand SLTs at the school checks whether or not this or that selected audio-visual aid is suitable for these MHC (the usability of the aids). Pedagogues, in turns, try their best not to misuse these audio-visual aids to avoid the disadvantages and consequences that might result from such procedure. In order to avoid this unintentional misuse of audio-visual aids, some specialists are of the view that audio-visual aid (s) should be pre-tested to see to what extent it will be helpful as a means of treatment. In their article titled: "People with learning disabilities" published in 1993, Dockrell et al., emphasize the importance of addressing "the extent to which the assessment procedures may be biased-either in terms of the materials used or the assessment situation itself." (Dockrell et al., 1993, P.276)

al-Dishtī (1988), al-Ḥāj (1995), Anraws(1999), Mayer(2001), Muștafā (2008), Nabhān (2008), and Hejāzī (2009) all agree that using audio-visual aids properly help improve learner's 
performance. 'Aḥmad (1996), Lāl\&al-Jundī (1994), Manșūr (1983), 'abdu-Hāshim \& al-Dulaymī (2007) and al-Baghdādī (1998) add that audio-visual aids have to be used according to the learner's ability. Furthermore, Manșūr (2001), Mutawe'a, Badrān and 'Atya (1979), and Hannatirzī (1962) are of the viewpoint that misusing audio-visual aids may confuse learners which lead to bad effects andunsatisfied results.

Syllabuses' designers authorize pedagogues, psychoneurolinguists and SLTs to penalize their MHC when they misuse audio-visual aids. This punishment, according to the syllabi, does not legalize using sticks. It only means that pedagogues can show anger with MHC bad behavior, threating that $\mathrm{h} / \mathrm{she}$ will not reward to them, etc. However, eminent names in psychology including Freud (1909/1953-1974), Thorndike (1911, 1932) and Skinner (1938, 1953) are all agreed on the fact that punishment as a technique should be avoided. As a matter of fact, not all what has been written by syllabuses' designers are followed by schools teaching students of special needs. For example, the audio-visual aids they recommend are not all available. Principals and supervisors of these schools complain that some audio-visual aids are expensive; that is why they do not buy them. They also add that it is a global phenomenon. Such justification, to some extent, is acceptable. Brolin \& Kokasa (1979), for example, claim that "major changes in the educational structure include increased allocations of monies to support special programs; integration of handicapped students into regular education classrooms; lawsuits to insure that handicapped students participate in daily class activities; and applications of technology in the development of instructional media to assist teachers and students."(Brolin \& Kokasa, 1979, Introduction)

\subsection{Audio-visual Aids Used at Schools for Students of Special Needs}

Using audio-visual aids at schools teaching students of special needs is remarkable. Pedagogues and language experts added audio-visual aids to the exercises so that MHC repeat them many times until they become capable of articulate target sounds accurately and fluently. For example, according to the curricula and syllabi of al-Malādh school, audio-visual aids include actions and multimedia. In order to use audio-visual aids perfectly, MHC are divided into small groups or even pairs if necessary. If one of the exercises, for example, determines that for teaching new vocabulary, word lists should be presented on cards, the same words are separately written on small cards. Mirror is also recommended where MHC can see their mouths when articulating sounds and compare their performance with their pedagogues, psychoneurolinguists and SLTs. Candles are also used to stimulate learners to produce the flow of air needed for pronouncing specific voice sounds. Commenting on such uses, Hult (1986) adds:"...It gives children who have specific auditory and/or visual difficulties a logical progression which provides the maximum opportunity for overcoming them." (Hult, 1986.P.85)

To begin with, pedagogues, psychoneurolinguists and SLT start prepare MHC psychologically by playing with them to break the screen of frightening and shyness. These activities include: Closing eyes, listening to music, physician's games (action), cubic, etc. Secondly, the pedagogues, psychoneurolinguists and SLTs start the exercises of articulation by asking MHC to take their tongues out slowly and vice versa, move their lips, etc. The 
purpose is to imitate the sounds they hear. The pedagogue, psychoneurolinguist or SLT then asks them to name the source of the sound, and link it with the picture they see. Finally, MHC are given various psychological drills on how to pronounce a particular sound using breath, etc. Since behavioral progress of MHC is strengthened by contingent rewards, pedagogues, psychoneurolinguist and SLTs of al-Malādh school always encourage their MHC by buying them some gifts (sweet candy, cakes, cookies, posters, etc.).Such methodology has positive feedback which is most likely in the feats performed by companies' outstanding experts rewarded with money and certificates. However, positive reinforcement is extremely important in the cases of MHC. It is according to Walker (1975) "... of interest for two separate reasons; first as one of the most powerful techniques and the second reason is almost a philosophical one." (Walker, 1975, P.46)

Due to the fact that some of these audio-visual aids are dangerous, responsible persons at these schools keep them out of the hand of these MHC as a safeguard to ensure their ultimate protection and safety. Supporting this procedure, Goldman \& Guerry (1983) have rightly pointed out that "... In the case of children with attention disorders, these materials should be kept out of view as much as possible." (Goldman \& Guerry, 1983, P.18)

Having finished their study, a committee examines the performance of MHC. This committee includes: Pedagogues, Psychoneurolinguists and SLTs. Strictly speaking, the test is not watertight, yet some psychoneurolinguists recommend some other parties to be involved. al-'Azzā (2009) listed some of these parties which include: "Psychochiatrists, specialist in assessment, social supervisor, and educational advisor" (al-'Azza, 2009, P.75)

Using radio cassettes, the school pedagogues, psychoneurolinguists and SLTs ask MHC to listen to anything they are familiar with. Unconsciously, MHC start to name that thing (e.g., animal's voice) they have just listened to. As a matter of fact, such strategy is one of Piaget's theory of basic elements. According to Piaget (1975), actions come before conceptualization. Moreover, there is a logic of action prior to and independent of the development of expressive language. In light of the above mentioned hypothesis, MHC should learn the meanings before they learn words. Of course, everyone in the class almost interacts with the pedagogues, psychoneurolinguists and SLTs, especially those from 6-10 years old, and that is very natural. In her article titled:" Problem Solving Communication and Complex Information Transmission in Groups" published in 1981, Beaudichon has studied interaction among $\mathrm{MHC}$, and found that "the 6- and 10-year-olds spoke a great deal, producing complicated effects with both disruptive and positive consequences." (Beaudichon, 1981, P.368)

School's pedagogues, psychoneurolinguists and SLTs try their best to create an interaction class where all MHC participate with each other. What enhanced the staff to do so is that they observed that MHC learn some communication skills from each others. Those who are unable to articulate certain sounds for example try to imitate the way(s) others use. As time passes, their pronunciation is ameliorated. Beveridge (1976) investigates the systematic ways through which MHC can learn communication skills from each other. According to Beveridge, "results so far have been encouraging. They have showed considerable ability to 
learn." (Beveridge, 1976, P.152)

The school's pedagogues, psychoneurolinguists and SLTs also try different audio-visual aids to make children listen to them directly, thereby maintain their attentions. According to al-Hāshimī \& al-'Izzāwī (2005),"Listening directly to the speaker consists of two elements: Sound communication and signals and gestures". (al-Hāshimī \& al-'izzāwī̄, 2005, P.183)

Things do not go always as someone may wish. Some problems may hinder the educational process in MHC schools. Roys \& Zabel (1993) summarize these problems by stating that:"Spelling, punctuation and grammar problems are the most linguistic problems facing students who have difficulties in learning and which affect their ability on reading and writing." (Roys \& Zabel, 1993, P.465)

Although tape slide is not used a lot in the school (in comparison to other audio-visual aids), it does not mean that this audio-visual aid is not used at all. Highlighting the importance of such aid, Lorac \& Weis (1981) have rightly observed "Several groups worked through the medium of tape-slide. These included trainee electricians, craft and technician engineers, painters and decorators and nursery nurses. The aims are more similar to those of previous work to generate oral and social competence and general communication skills." (Lorac \& Weis, 1981, P.115)

Computers are also considered essential audio-visual aids used at MHC school. Needless to saythat studying human behavior needs to be influenced by computer. Pedagogues, psychoneurolinguists, and SLTs conclude by saying that comprehensive reviews of the scientific and therapeutic endeavors are variously linked with the video medium. To that end, al-Fār (1998) puts a comprehensive framework for computer's uses in education and learning and lists them as follows:

1. Computer Assisted Instruction(CAL).

2. Computer Management Instruction (GMI).

3. Computer Based Thinking(CBTH).

Programs related to social activities are also highly considered in MHC schools. Pedagogues, psychoneurolinguists and SLTs believe that such activities complete audio-visual aids. They believe that social activities are very important, namely in the field of special education. According to language experts, such activities may help MHC face their psychological and mental challenges and improve their intellectual performance. Commenting on this fact, Egan (1975) suggests that: "It is utterly amazing that interpersonal skill building is left so much to chance in our society." (Egan, 1975, P.21)

Cassettes are also some other audio-visual aids used by MHC schools. In addition to their reasonable prices, cassettes are also easy to listen to at anytime, especially when it becomes relevant to MHC individual needs and/ or treat some of their mental impairments like the pronunciation deficits, etc. As Marash (1962) points out" The correct and artistic use of pitch, sound, pace, pause, phrasing, inflexion, tonal amount and quality" (Marash, 1962, P. 99) 
However, al-Zayāt (2007) believes that learning difficulties need more than one approach to be treated. He lists some of these approaches and mentions them as follows: "Medication Therapy Approach, Behavioral Therapy Approach, Cognitive Therapy Approach, Neuropsychological Therapy, and Multi-Integrative Therapy Approach." (al-Zayāt, 2007, P.347)

In his famous book titled: "Teaching Technology ", al-Manșūr (1989) mentions different names for audio-visual means and prioritizes them according to the stages of time as follows: Visual Instruction, Audio-Instruction, Audio-Visual Instruction, Teaching Aids, Instructional Aids, Means of Communication, Educational Media, Instructional Technology and Educational Technology. (al-Manșūr, 1989, PP.35-38)

Because of their importance to children in general and MHC in particular, models are used in MHC schools. Pedagogues, psychoneurolinguists and SLTs tend to use these models as means that simplify complicated images and bring them close to mind. There are many types of models used at this school: Solid model, section model (longitudinal/cross), transparent model, cut-a-way model, model with removable parts and working model. However, some of these models are bought by the school and some others are home made. Pedagogues and SLTs with the help of psychoneurolinguists working at the school make these models from available materials including papers, sponge, clay, gypsum. Encouraging them to use such audio-visual aids, al-Sayid (1977) adds: "putty and tapes can also be used in making models" (al-Sayid, 1977,P.197)

Attempting to communicate with these MHC, some SLTs of this school use the most suitable audio-visual aids that might be helpful for their students. One of these aids is the Color Pattern Scheme (John Lea, 1970) where certain colors are assigned for each part of speech. In fact, this method proved itself as one of the audio-visual aids that can be used for MHC. Hult (1986) has rightly stated:"Most children learn first to speak, then to decode print into meaning and decode speech into writing. They are learning language through writing, reading and speaking." (Hult, 1986, P.14)

Pedagogues, SLTs, psychoneurolinguists, and language experts all agree that MHC themselves could be used as aids. To that end, Eibeed (2000) suggests some activities wherein MHC can be involved like "identifying the parts of their bodies, how some of them work (watching their inspiration and expiration), tasting sugar, salt and fruit and touching textiles and other materials." (Eibeed, 2000, PP.302-3)

Such activities can also be done at home because they are free and will not cost MHC's poor families anything. To that end, Mialaret (1956) admits that one of the reasons why teaching MHC is taught is that "...present complexity of social and psychological phenomena." (Mialaret, 1956, P.159)

Mitchel (1976) casts light on the problems the families of MHC are facing and how these 
problems are directly related to MHC. He lists these issues and mentions them as follows:

1- Relative to the behavior of mothers in interactions with their normal children, the behavior of mothers in interactions with their mentally handicapped children matched on chronological age is characterized by:

(a) A higher frequency of imperative sentences (Buium et al. 1974); controlling behavior such as ordering, prohibiting, and restraining (Kogan et al. 1969); mending ( Marshall et al. 2011);

(b) A higher number of utterances yet a lower mean length of utterance (Buium et al. 1974);

(c) A higher frequency of grammatically incomplete sentences and single word responses (ibid. 1974);

(d) A lower frequency of conjunctions, indefinite pronouns, and Wh. Type questions (ibid. 1974);

(e) A higher frequency of questions in which they already know the answer (Kogan et al. 1969);

(f) A higher frequency of providing physical relevant to a task ( Smith et al. 1973);

(g) More frequent shifts among motivation, control, and orientation categories(Dolley 1974);

(h) A less rapid tempo in shifting between elaborated and restricted patterns (ibid. 1974).

2- Relative to non-mentally handicapped children in interaction with their mothers, mentally handicapped children matched on chronological age are:

(a) More unintelligible (Kogan et al. 1969);

(b) Less soliciting or accepting of control (e.g., by asking questions, requesting guidance, and expressing ideas tentatively.(ibid. 1969);

(c) More likely to be echoic (i.e. to repeat responses made by the mother ( Marshall et al. 2011)

(d) Less likely to include tracts, minds, and inter verbals in their speech ( ibid.1973)

3- Relative to teachers, mothers interacting with their mentally handicapped children are:

(a) Less likely to use tangible rewards ( Smith et al. 1973);

(b) Less likely to provide cues for correct matching on a match to sample task (ibid. 1973).

4- Intervention studies in the field of interactions between mentally handicapped children and their mothers have shown that:

(a) Mothers who are trained to arrange materials obtain higher child performance scores on a match to sample task than do mothers trained to maximize positive feedback to each correct child response or mothers who do not receive training on any specific aspect of teaching style( Filler et al., 1973); 
(b) Mothers who are trained to utilize behavior modification principles, when compared with "no treatment" controls generate effective free play interactions between themselves and their children (Mash \& Terdal 1973);

(c) Relative to no treatment controls, children of mothers who participate undirected language improvement programmed involving variety of approaches make gains on an articulation test and ' experience tests' with outings, neighborhood life, and adult activities(Jeffree \& Cashdan, 1971).

(d) Mothers trained in employing behavior shaping procedures, generating new training stimuli and immediately generalizing language changes from imitation to parallel conversation and play activities, affect increases in utterance length and semantic grammatical complexity in their children's language (McDonald et al. 1974) (Mitchel, 1976, PP.179-80)

The school's pedagogues, SLTs, and psychoneurolinguists keep always advising MHC's parents to keep watching their children at home and inform them (pedagogues, SLTs, and psychoneurolinguists) when they notice something unusual. According to McDavid \& Garwood(1978) "Who seeks to work effectively with children to facilitate their growth and development must learn to be observant all of the time, to be alert and watchful of everything the child is doing, and to relate these observations over time to an understanding of the child's gradual progression toward mature and competent behavior." (McDavid \& Garwood, 1978, P.18)

However, in case the behavior of these MHC at home changes from that at school, the school pedagogues, SLTs and psychoneurolinguists study these MHC individually as case studies, especially if all case studies' questions are available. These questions according to Learner (1976) should include:

1. Questions about the general background of the child and his health case.

2. Questions about the present activities of the child.

3. Questions about physical grow up of the child.

4. Questions about personal and social grow up. (Learner, 1976, P. 91)

When the school realizes that MHC's language components and skills are improved, they send them to official schools whereby they can finish their education with normal students. Before undertaking this procedure, they first obtain the agreement of the school's pedagogues, SLTs and psychoneurolinguists. It should be clearly stated here that parents recognize their MHC reaching the milestone; the more intervention may help them reach their full potential related to their retardation (Howard-Barr et al., 2011).

The idea of sending MHC to finish their learning with normal children in other public schools is objected by too many experts in the field (Harūn, 1985; Ptnam et al., 1989; Rowden, 1990; Hindāwī; 1993; al-Shāfi '̄i, 1993; Abdulkarīm, 1994; al-'Atyah, 1995; Bang\&Lamb, 1996; Bakhsh, 1997; 1998). Shash (2002) also agrees that "behavioral disorders in MHC become 
less after training programs with a group of merging which shows that these kinds of programs run by normal and MHC's interactions have played an important role in decreasing behavioral disorders among MHC." (Shash, 2002, P.296)

Eibeed (2000) lists three differences in learning through which one can easily distinguish normal children from mentally handicapped children and mentioned them as follows: "Transfer of learning, memory, and language characteristics." (Eibeed, 2000, P.160)

\section{Results \& Recommendations}

\subsection{Results}

The study examines the way, pedagogically and Psychoneurolinguistically speaking, audio-visual aids could help solve the problems of 157 MHC. Problems of these MHC include expressive language which is characterized by single words interspersed with jargon which usually has the intonation of normal speech. Their vocabularies consist of single names of objects, and few verbs. However, most of these MHC are able to copy sounds in isolation, but in most of the time, they find it difficult to retain and reproduce more than one sound at the same time. They often use one sound to indicate a whole word or phrase. Nearly all MHC have such great difficulty in the comprehension of verbal language, and also have a comparable difficulty in its production.

In comparison to their colleagues who are studying under normal educational environment (with no audio-visual aids), most MHC under the study develop their mental abilities at schools of special education wherein audio-visual aids are essential parts of the requirements. More importantly, many of them reach particular milestone slightly late or early. It all depends on how and why these audio-visual aids are used.

Audio-visual aids used at MHC schools are realia, models, pictures, computer, and T.V. Other audio-visual aids include: Powder of chalks, boards, pens, balls that make sounds, colors, mirrors, pianos, water, soap, pipes, whistles, cards, pictures, etc. They all found to be useful for $\mathrm{MHC}$ as they improve their performance. Again, these audio-visual aids proved themselves in improving the level of MHC who use them as means of entertainment. In conclusion, the merits and advantages of these audio-visual aids are endless due to the fact that they save time, effort and money.

\subsection{Recommendations}

In order to help children with potential problems (e.g., MHC) reach healthier future, schools teaching students of special needs should realize the impact of disability's development and invest more audio-visual aids. Such procedure is supposed to help parents measure their child progress in terms of milestone that monitor more than just a physical growth. In fact, the role of audio-visual aids is delimited to treatment; rather, they play a crucial role in diagnostic process by developing a scientific mechanism based on observing children, notably MHC in terms of how they play, learn, speak and act. For that matter, the present study recommends using them when teaching children in general and MHC in particular. It is also recommended by this study that the pedagogic system followed by al-Malādh school for teaching students 
of special needs should be followed by all other MHC schools. The pedagogic system of the above mentioned school including teaching methodology, the way the available audio-visual aids are utilized, the staff (Pedagogues, SLTs, and Psychoneurolinguists) should be taken as a template and applied to all other schools teaching students of special needs.

Parents may notice that their MHC do not act like other children including their siblings. They should inform the school where pedagogues, SLTs, and psychoneurolinguists will help assign audio-visual aids appropriately that fits with these MHC. Parents are also recommended to use available audio-visual aids when they teach their MHC at home. Pedagogically speaking, these audio-visual aids require encouraging MHC to speak more than one simple phrase accurately and fluently. They also help MHC to follow simple instruction and also point to objects, or anything visual when they name it. Continuous tracking of the way MHC play, speak, learn and act is really important and that is what al-Malādh school does and what other schools of the same natureare recommended to do. Several questioned should be posed by pedagogues, SLTs, and psychoneurolinguists before applying any audio-visual aid. Why am I using this or that particular aid (a model of train for example)? Why not another/ other aid(s)? How suitable is this or that aid for MHC? When shall I use this or that audio-visual aid? To do so, these parties should connect with MHC to detect the potential problems they face. It is the best way for diagnosing MHC; therefore, undertaking the suitable procedure to solve their problem. Ultimately, when accounting for such problem, it should be known that home observation is very important; therefore, if parents notice that audio-visual aids do not improve the performance of their MHC, the school pedagogues, SLTs, and psychoneurolinguists should be informed immediately.

\section{References}

'Āmir, Ṭ., \& Muḥammad, R. (2008). Dhawī al-lḥtiyajat al-Khāssah Ṭ1 Mu'assasat . al-Qāhirah: Ṭaybah Lil-Nashr Wa al-Tawzi`a .

'Abdul-Ghaffār, A. (2003). al-Ri'āyah al-Tarbawiyah Lidhawī al-lḥtiyājat al-Khāssah . al-Qāhirah: Dār al-Fajr Lil-Nashr Wa al-Tawzía .

'Abdul-Hāshimī, '., \& al-Daylamī, Ṭ. (2008). Istrātījiyat Hadîthah FI Fan al-Tadrīs . 'Ammān: Dār al-Shurūq Lil-Nashr Wa al-Tawzī‘a .

'Adas, M. (1998). Șu'ubāt al-Ta‘allum. TT1 . 'Ammān : Dār al-Fikr Lil-Ṭibā‘ah Wa al-Nashr Wa al-Tawzīa .

'Alī, I. (2008). Ri'āyat Dhawī al-Ihtiyājāt al-Khāssah Fı al-Wațan al-'Arabì Bayn al-'Azl Wa al-Damj Tahriir al-Duktūr 'șām Tawfíq Qamar . al-Iskandariyah: al-Maktab al-Jāmi'iy al-Ḥadīth .

'Ibīd, M. (2000). al-Wasāíil al-T'alīmiyah FI al-Tarbìyah al-Khāssah. T1 . 'Ammān: Dār Șafā' Lil-Nashr Wa al-Tawzīa .

'Ibīd, M. (2000). T'alīm al-Aṭ̂āl al-Mutakhallifin 'Aqlīyan. Ṭ1 . 'Ammān : Dār Șafā' Lil-Nashr Wa al-Tawzīa. 
Aḥmad, A., \& Zāhir, A. (1996). Tiknulūjiyyā al-T 'alīm . al-Qāhirah: al-Maktabah al-Akādimīya .

al-'Ațīyah, A. (1995). Tanmiyat B'aḍ Jawānib al-Sulūk al-Takayufí Ladā 'Aiyinah Min al-Atfāl al-Mu'aāqīn 'Aqliyan Bidawlat Qatar. Kulliyat al-Tarbīyah -Jāmi'at al-Zaqāzīq, 1-8.

al-'Izzah, S. (2009). al-Madkhal Ilā al-Tarbiyah al-Khāṣșah Lil Ațāl Dhawī al-Ihtìājāt al-Khāṣṣah: al-Mafhūm Wa al-Tashkhịs- Asālīb al-Tadrīs. T11. 'Ammān: Dār al-Thaqāfah Lil-Nashr Wa al-Tawzīa .

al-Dashshī, 'A. (1988). Tiknulūjïya al-T‘alīm Fi Tațīr al-Mawāqif al-T'alïmīyyah. T11 . al-Kuwayt: Maktabat al-Falāḥ Lil-Nashr Wa al-Tawzīa .

al-Ḥāj, F. (1995). Athar Taqniyāt al-T‘alīm 'Alā al-Dhakā' al-Madrūs Lada al-Aṭāl FI al-Marḥalah al-Ibtidā'iyyah. T1. Ar-Riyāḍ: Dār al-Hudā Lil-Nashr Wa al-Tawzía.

al-Hāshimī, 'A., \&al-'Izzāwī, F. (2005). Tadrīs Mahārat al-Istimā‘a Min Manzūr Wāqiíty.Ṭ1. Baghdād: Dār al-Manāhij Lil-Nashr Wa al-Tawzī‘a.

al-Jābirī, M., Muntașir, 'A., \& Fayzal, ‘. (2008). al-Hāsūb FI al-T'alīm . al-Qāhirah: al- Sharikah al-'Arabīyah al-Muttaḥidah lil-Taswīq wl al-Tawrīd .

Almeida, M. (1987). Adult Mentally Retarded Persons as Language Mediators for Young Handicapped Children. Vanderbilt University Journal, 3-18.

al-Mūsā, 'A., \& al-Mubārak, A. (2005). al-T'alīm al-lliktirūnī. T11 . Ar-Riyaḍ: Mu'assat Shabakat al-Bayānāt.

al-Niwāyah, A. (2007). al-lstikhdāmāt al-Tarbawīyah Litiknulüjiya al-T'alīm. Ṭ1 . 'Ammān: Dār Kunūz al-M'arifah al-'ilmiyyah Lil-Nashr Wa al-Tawzīa.

al-Sayid, M. (1977). al-Wasāíil al-T'alïmīyyah Ṭ1 . 'Ammān : al-Mu'allif.

al-Zayyāt, F. (2007). Su ‘ūbāt al-Ta'allum: al-Istratijīyyāt al-Tadrīsìyyah Wa al-Madākhil al-'Ilājīyyah. T1 . al-Qāhirah: Dār al-Nashr Lil-Jāmi‘aāt.

Bacon, W. (1976). A Comparison of Two Science Teaching Methods for Educable Mentally Handicapped Children. Loyola University of Chicago, 4-11. (Publication No. AAT 7615457).

Bang, M., \& Lamb, P. (1996). The Impact of Inclusion of Students with Challenging Needs. Annual Conference of the Association for Persons with Sever Handicaps, 13-27.

Bayūmī, K., \& Jamāl, N. (1998). Siyāsāt T'alìm al-Ațāl al-Mu'āqīn Fì al-T'alīm al-Asāsī . al-Qāhirah: Dār al-Nashr Lil-Jāmi'aāt .

Berry, P. (1973). Imitation of Language: A Psycholinguistic Assessment Technique in Severe Sub normality. University of Manchester Journal, 1-5. 
Berry, P. (1976). Language and Communication in the Mentally Handicapped. Manchester: Arnold(Publishers)Ltd.

Buium, N., Rynders, J., \& Turure, J. (1974). Early Maternal Linguistic Environment of Normal and Down's Syndrome Language Learning of Children. Am J Mental, 52-58.

Burroughs, E. (2011). The effects of instructional mode on the skill acquisition of a recreation/leisure task by elementary students with severe mental retardation. Ball State University, 8-16. (Publication No. AAT 9222619).

Colette, S., \& Cardina-Stritch-Coll, M. (1965). Research Abstract. 1-4.

Dagger, J. (2011). Effects of model status and efficacy upon acquisition of a complex motor skill in mildly retarded and nonhandicapped children. University of Virginia Journal, 12-19. (Publication No. AAT 9008208).

Dipalma-Meyer, F. (2011). Teaching Adaptive Behavior to Noncategorical Handicapped Children and Adolescents: The Efficacy of a Social Learning Curriculum (Learning-Disabled, Emotionally Disturbed, Mentally Retarded, Competence, Social Skills Training). Journal of Columbia University Teachers College, 13-24.(Publication No. AAT 8611671).

Dockrell, J., \& McShane, J. (1993). Children's Learning Difficulties: A Cognitive Approach. Oxford: Blackwell.

Dolley, D. (1974). Mothers as Teachers: Instruction and Control Patterns Observed in Interaction of Middle-Class Mothers with Trainable Mentally Retarded and nonretarded Chidren. Indiana: Center for Innovation in Teaching the Handicapped, Indiana University Press.

Egan, G. (1975). The Skilled Helper. Montery: Brooks Cole .

Filler, J., Bricker, W., \& Smith, R. (1973). Modification of Maternal Teaching Style: The Effects of Task Arrangement on the Match-to-Sample Performance of Delayed Children. Bricker and Bricker, 11-17.

Goldman, J., Stein, C., \& Guerry, S. (1983). Psychological Methods of Child Assessment. Routledge: Brunner Mazel, Inc. .

Grandguillot, S., \& Murmann, A. (2011). The Use of Computers in Special Education: The Example of French-Speaking Switzerland. The International Journal of Sociology and Social Policy, 4-6. (Document ID: 1123479).

Gregory, R. (1992). Psychological Testing: History, Principles, and Applications. Boston: Allyn\& Bacon. 
Ḥanātirzī, F. (1962). al-Wasāil al-Samíyah Wa al-Bașariyah al-Musāidah FI T'alīm al-Lughah al-'Arabiyah . Bayrūt: Maktabat Rās Bayrūt .

Hārūn, Ṣ. (1985). Dirāsat Athar al-Barāmij al-Tarbawiyah al-Khāssah Fı Tawāfuq al-Mutakhallifin 'Aq/īyan Fial-Marhalah al-Ibtidā'iyah Kulliyat al-Tarbiyah. al-Qāhirah : Jami'at 'Ayn Shams.

Higgins, C., Rusch, R., \& Albany-public-schools, N. (1967). Development and Evaluation of Auto-Instructional Programs in Arithmetic for the Educable Mentally Handicapped. The North Central Association Quarterly, 38-47.

Hijāzī, ' (2008). Handasat al-Wasāíl al-T'alïmiyah. Ṭ1. 'Ammān: Dār 'Usāmah Lil-Nashr Wa al-Tawzīa.

Hindāwī, Ș. (1993). Madā Fāilīyat Nizām al-Damj Fi Taḥsīn B'ạ Jawānib al-Sulūk al-Tawāfuqī Lil-Talāmīdh al-Mutakhallifin 'Aqliyan al-Qābilīn Lil-Ta'allum . al-Qāhirah: Kulliyat al-Tarbiyah Jāmi'at 'Ayn Shams.

Howard-Barr, E., Rienzo, B., Pigg, R., \& James, D. (2011). Teacher Beliefs, Professional Preparation, and Practices Regarding Exceptional Students and Sexuality Education. The Journal of School Health, 18-27. (Document ID: 831630951).

Husayn, S. (1998). al-Mu'awwaqīn Fì Būr Sa'īd: Dirāsah Maydānīyah lil-Khadamāt al-Ḥāliyah Wa al-Iḥtīyājāt al-Mustaqbalīyah Fi Taqrīr Wa Buḥūth Wa Dirāsāt Wa Tawṣīyāt . al-Mu'tamar al-Sādis, 1-7.

Jack, H., Johnson, L., \& Temple-Univ, P. (1971). Physical Activities for Mentally and Emotionally Handicapped Children. Temple University Journal, 34-45.

Jamīl, S. (1998). Naḥwa Hayātin Af̣̣al Lil-Ṣum FI Taqrīr Buhūth Wa Tawșìāt al-Mu'tamar al-Sādis Naḥwa Mustaqbalin Afọal Lil-Mu'awwaqīn . al-Qāhirah: Dār al-Nashr Lil-Jāmi'aāt.

Jeffree, D., \& Cashdan, A. (1971). Severely Subnormal Children and Their Parents: An Experiment in Language Improvement. Brit. J. Educ. Psychol., 184-193.

Jooste, C. (2011). The value of Feuerstein's Structural Cognitive Modifiability Theory for the education of mentally handicapped pupils. University of South Africa Journal , 34-52.(Publication No. AAT 0599664).

Kogan, K., Wimberger, H., \& Bobbitt, R. (1969). Analysis of Mother-Child Interaction in Young Mental Retardates. Ch.Dev., 799-812.

Kokaska, B. (1979). Career Education for Handicapped Children and Youth. Colombus, OH: Bell\&Howell Company . 
Lāl, Z., \& al-Jundī, 'A. (1995). Muqaddimah Fì al-Ittișāl Wa Tiknulujīya al-T'alīm. T2 . Ar-Riyāḍ: Maktabat al-'Ibīkān .

Learner, J. (1976). Children with Learning Disabilities. Boston: Houghton Mifflin Co. .

Lorac, C., \& Weiss, M. (1981). Communication and Social Skills. London: Schools Council Publications.

McDonald, J., \& Blott, J. (1974). Environmental Language Intervention: The Rationale for A Diagnostic and Training Strategy Through Rules, Context, and Generalization. J.Sp. and Hear. Dis., 244-256.

Manșūr, A. (1983). al-Kitāb al-Dawrī Fì al-Taqniyat al-Tarbawiyah . al-Kuwayt: al-Markaz al-'Arabī Lil-Taqniyāt al-Tarbawiyah .

Manșūr, A. (1989). Tiknulūjiya al-T'alīm Wa Tanmiyat al-Qudrah 'Alā al-Tafkìr al-lbtikārī. Ṭ1 . al-Manșūrah: Dār al-Wafā' Lil-Ṭibā'ah Wa al-Nashr Wa al-Tawzī‘a .

Manșūr, A. (2001). Asāsiyāt Tiknulujijya al-Tarbiyah . Dimyāț : al-Maktabah al-'Așriyah.

Marash, J. (1962). Effective Speaking. London : Harrap.

Marks, G. (2011). A comparison of auditory feedback training with combined auditory and visual feedback training in teaching mentally retarded and multi-handicapped children head control. Queen's University at Kingston, 34-55.(Publication No. AAT MK55965).

Marshall, N., Herens, J., \& Goldstein, C. (2011). Mothers and Their Retarded Children VS Mothers and Their Nonretarded Children. Am. J. Mental Def. , 415-419.

Mash, E., \& Terdal, L. (1973). Modification of Mother-Child Interactions .Playing with Children. Mental Retard, 44-49.

Matthews, W. (2011). An evaluation of the method of teaching the mentally handicapped in Hackensack. Journal of Kean University, 16-24.(Publication No. AAT EP11365).

McConachie, H., \& Mitchell, D. (1985). Parents Teaching Their Young Mentally Handicapped Children. Journal of Child Psychology and Psychiatry and Allied Disciplines, 389-405.

McDavid, M., \& Garwood, C. (1978). Understanding Children: Promoting Human Growth. D.C: Health and Company .

Morales, F., \& Macarena, M. (2011). A Single Subject Design to Test Selected Science Process Learning with Mentally Handicapped Children. Washington State University Journal, $11-21$. 
Muḥammad, M. (1999). Tiknulūjiya al-Ta'alïm: Dirāsāt 'Arabiyah. Ṭ1. al-Dawhah: Markaz al-Kitāb Lil-Nashr al-Qāhirah.

Muller, F. (2011). Orthopedagogic Guide Lines for a Curriculum-Design Concerning the Mentally Handicapped Child (Afrikans Text). University of Pretoria Journal, 44-53.(Publication No. AAT 0537294).

Muștafā, A. (2008). al-Wasāiț al-Muta'addidah al-Tafāuliyah: Ru'yah T'alìmiyah FI al-T'allum 'Abra Barmajijyat al-Wasāiț al-Mut a'addidah al-Tafā'uliyah. T11 . al-Qāhirah.

Mușțafā, A. (2008). al-Wasāiț al-Muta'addidah al-Tafāuliyah: Ru'yah T'alïmiyah Fl al-T'allum 'Abra Barmajiyyat al-Wasā'ịt al-Mut a'addidah al-Tafā'uliyah. T11 . al-Qāhirah: 'Ālam al-Kutub.

Muștafā, A., \& Fihīm, A. (2004). Mahārāt al-Qirāah al-Iliktrūniyah: Ru'yah Mustaqbaliyah Litațīr

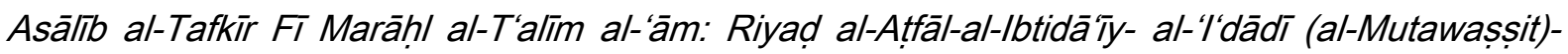
al-Thānawī Ṭ1 . al-Qāhirah: Dār al-Fikr al-'Arabī .

Muțāwi‘a, I., Badrān, M., \& 'Atiyyah, M. (1979). al-Wasāill al-T'alïmiyah . al-Qāhirah: Maktabat al-Nahḍah al-Mișriyah .

Nabhān, Y. (2008). al-Asālỉb al-Hadîthah Fì at-T'alīm Wa at-Ta'allum . 'Ammān: Dār al-Yāzūrī al-'Ilmīyah Lil-Nashr Wa al-Tawzī'a .

Nocera, S. (2011). A Descriptive Analysis of the Attainment of Selected Musical Learnings by Normal Children and by Educable Mentally Retarded Children Mainstreamed in Music Classes at the Second and Fifth Grade Levels. The University of Wisconsin Journal, 37-49. (Publication No. AAT 8126642).

Olivier, M., \& Williams, E. (2005). Teaching the Mentally Handicapped Child: Challenges Teachers Are Facing. International Journal of Special Education, 19-31.

Orfittelli, M. (2011). A Comparative Study of Young Normal, Learning Disabled, Educable Mentally Handicapped and Training Mentally Handicapped Children in Physical Growth Measurements, Motor Skill Abilities and Social Age Equivalency. The University of New Mexico Journal, 43-56. (Publication No. AAT 0336434).

Phaup, W. (2011). A Comparison of Two Methods for Teaching Keyboarding to Educable Mentally Retarded Students . The University of Alabama Journal , 41-56.(Publication No. AAT 8713437).

Piaget, J. (1975). The Psychology of Consciousness. San Francisco: W.H. Freeman.

Roesene, P. (1982). Instrumental Music...A Success Opportunity. Music Educators Journal, 37-39. 


\section{Macrothink \\ International Journal of English Language Education ISSN 2325-0887 \\ 2013, Vol. 1, No. 2, Special Issue}

Rowan, V., \& Pear, J. (1985). A comparison of the effects of interspersal and concurrent training sequences on acquisition, retention, and generalization of picture names. Applied Research in Mental Retardation, 127-145.

Rowden, L. (1990). Social Competence in Institutionalized Mentally Retarded Adults: Concurrent and Predictive Correlates. University of Waterloo Journal, 1.

Sechrest, M. (2011). The Appropriateness of the North Carolina Minimum Competency Test for Mentally Handicapped Students. Journal of the University of North Carolina at Greensboro, 18-24.(Publication No. AAT 8210369).

Skinner, B. (1938). The Behavior of Organisms. New York: Appleton.

Skinner, B. (1953). Science and Human Behavior. New York: Macmillan .

Smith, R., Filler, J., Bricker, W., Robinson, C., \& Vincent-Smith, L. (1973). Evaluation of Teaching Style: A Comparison of Teachers and Mothers. Bricker and Bricker, 41-62.

Spenciner, L. (2011). Tapping additional computer capabilities: Use of a speech synthesizer to increase a sight vocabulary in mentally handicapped students. Journal of Boston College, 31-39. (Publication No. AAT 9022363).

Steenkamp, C. (2011). The Vocational Need of the Mentally-Handicapped Puiple of the Special School. University of South Africa Journal, 21-39. (Publication No. AAT 0560965).

Stowtschek, J., \& Hendrickson, R. G. (1980). Instructional Materials for Exceptional Children: Selection, Management, and Adaptation. Aspen Systems Corporation. Rockville: Aspen System Inc. ISBN-13: HYPERLINK "http://www.alibris.com/search/books/isbn/9780894432774" 9780894432774. ISBN: HYPERLINK "http://www.alibris.com/search/books/isbn/089443277X" 089443277X. Alibris ID: 11358846000.

Thorndike, E. (1911). Animal Intelligence. New York: Macmillan.

Thorndike, E. (1932). The Fundamentals of Learning . New York: Teachers College, Columbia University .

Upham, A. (2011). Curriculum packet serving autistic, educable, and trainable students with mental impairments. Grand Valley State University Journal, 19-28. (Publication No. AAT 1375990).

Van Vuuren, A. (2011). The education and teaching of severly mentally retarded children: A historic-pedagogic perspective. University of South Africa Journal, 11-19.(Publication No. AAT 0666760). 


\section{Macrothink \\ International Journal of English Language Education ISSN 2325-0887 \\ 2013, Vol. 1, No. 2, Special Issue}

Walker, S. (1975). Learning and Reinforcement. London: Methuen Co. Ltd.

Walrich, R. (2011). The Development of a Science Handbook for Teachers of Educable Mentally Handicapped Children. Journal of Columbia University Teachers College, 34-47. (Publication No. AAT 8123007).

Wiggin, R. (1961). Art Activities for Mentally Handicapped Children. Studies In Art Education, 388-402.

Wilson, B. (1985). "Portage" for neurological patients. International Rehabilitation Medicine, 6-8.

\section{Glossary}

$\mathrm{CALL}=$ Computer Assisted Language Learning.

$\mathrm{MHC}=$ Mentally Handicapped Children.

SLTs $=$ Speech Language Therapists.

\section{Copyright Disclaimer}

Copyright reserved by the author(s).

This article is an open-access article distributed under the terms and conditions of the Creative Commons Attribution license (http://creativecommons.org/licenses/by/3.0/). 